\title{
A pesquisa em materiais dentários
}

A indústria dos materiais dentários e medicamentos está presente em nossa especialidade desde seu início. A avaliação do comportamento clínico e laboratorial dos materiais é fundamental para uma prática segura com o paciente, e histórias incríveis são emolduradas nos retratos dos avanços científicos e tecnológicos nessa área.

A evolução da indústria nesse campo está associada a uma dessas histórias fascinantes e se constitui em um dos mais eloqüentes casos de serendipity* que ilustram nosso memorial. Um aluno de 18 anos do Colégio Real de Química de Londres, William Henry Perkin, se embrenhou durante as férias no projeto de sintetizar o quinino, uma droga contra malária muito em voga em meados do século XIX. Ele começou seus experimentos com carvão mineral e produziu a anilina. A partir desta, conseguiu gerar um misterioso pó negro. Em virtude de seu treinamento em química e sua curiosidade, tentou descobrir o que era aquele resíduo. Em pouco tempo se deu conta que o produto - a mauve -, quando misturado ao álcool, produzia uma incrível cor púrpura. Em vez de descartar o produto, Perkin testou se ele poderia colorir tecidos. Não apenas ele descobriu que a tintura pigmentava algodão e seda, como também que ela não saía quando lavada e não desbotava quando exposta ao sol. Ele convenceu o pai e o irmão de se desfazerem de bens para montarem uma fábrica de produção do pigmento; e foi o complexo industrial de tintas, erguido sobre seus ombros, que gerou as modernas indústrias de fármacos, explosivos, detergentes, plásticos e fibras sintéticas. Alguns anos depois, sintetizou o vermelho de alizarina. Corante aplicado à pesquisa biológica com várias finalidades, mostrando-se uma ferramenta valiosa que ajudou a desvendar parte dos mecanismos do crescimento ósseo, e a descobrir a causa da tuberculose e da cólera.

\footnotetext{
* Serendipity significa achado feliz feito ao acaso.
}

Especificamente dentro da Odontologia, uma das mais conhecidas histórias de serendipity foi a de Buonocore $^{1}$ ao vislumbrar as possibilidades de aplicação do condicionamento do casco de navios para adesão de resinas aos dentes. Ele também foi um fundador, não de uma indústria, mas de um novo campo dentro da Odontologia, que é o de sistemas de adesivos. Isso permitiu a melhora na qualidade estética das restaurações, tanto de dentes anteriores quanto de posteriores.

Buonocore também viabilizou que os anéis ortodônticos fossem limitados a algumas situações e aos dentes posteriores. As colagens de braquetes dominaram o cenário dos aparelhos fixos, melhoraram o status periodontal dos pacientes e permitiram que pacientes adultos pudessem se beneficiar dos tratamentos ortodônticos. E essas colagens continuam a evoluir.

O presente número da Revista dedica vários artigos à área de materiais ortodônticos. Um dos temas mais abordados é a colagem de braquetes. $\mathrm{E}$ isso permite que o leitor tenha facilidade de obter uma visão geral das dificuldades e soluções para várias situações clínicas, de forma concentrada.

Em última análise, os vários trabalhos objetivam testar se os avanços produzidos pela indústria iniciada por Perkin, e alavancada por Buonocore, se traduzem em vantagens clínicas para que todos nós, em nossos consultórios, possamos tomar melhores decisões clínicas.

Boa leitura.

Jorge Faber

Editor

\section{REFERÊNCIAS}

1. BUONOCORE, M. G. A simple method of increasing the adhesion of acrylic filling materials to enamel surfaces. J. Dent. Res., Chicago, v. 34, no. 6, p. 849-853, Dec. 1955. 